\title{
Plans for Planning-Some Hints on Buildings
}

Support for librarians, from a practicing architect, in the task of securing buildings which will fulfil library functions.

A large building program seems indiGovernments, both federal and state, have established postwar commissions to help in the financing of plans. Many institutions, including some libraries, are contemplating additions. Accordingly, there would appear to be prospects for librarians to get a hearing. If colleges are to undertake building, they might as well construct libraries as some of the projects they have in mind.

An effort on the part of librarians to come out with their projects, therefore, is in order. Those who have been suffering for years with obsolete plants might well take their courage in their hands and ask for their heritage.

This article is an endeavor to put before librarians some selling ideas and to explain the resistance they are bound to meet when presenting their problems. It is fair to say that librarians as a group are among the world's worst salesmen. They, like scientists, are so much occupied with their work and the service they are rendering to their communities or colleges that they have not the time to develop salesmanship. They are handicapped because their staffs are undermanned and have a multiplicity of duties which keep their minds away from publicity channels. And, like all patient individuals, they sometimes are exploited.

In their honesty of thought and purpose librarians have believed that if they were to come before the public or their boards of trustees with frank statements that they required new libraries, their words would be given proper weight. But not so. The listener always has a certain amount of inertia and generally he is not going to do much thinking about a library's needs. To put the idea across, the only way is to be prepared to sell it. To say to a lay group that a new library or a new addition is essential does not call to their minds any such picture as the librarian has and, indeed, it often is to speak a strange language. The hearer might be convinced by a detailed explanation, but those in authority to grant or allot money for a new building usually surround themselves with a defensive wall and will not devote the time necessary for the full presentation of the problem. They must have the facts predigested.

The author recently met this condition in a college. The library was in an old building, spreading out in all sorts of nooks and corners. It was almost impossible for the staff to function efficiently. There was no convenient place to unpack the books and there was no space to repair them. The cataloging had to be done in a small alcove. This situation had existed for many years, under the very noses of the trustees. They looked and said: "There are the books on the shelves, there are the students drawing the books, the librarian is busy running around, the library is functioning-what more can be wanted?"

In presenting the need for a new library 
to the trustees, the first step was to make a diagram of the existing library, showing the line of foot circulation as compared with the foot circulation in an idealized building. Then came a survey of the college's need for book space over the next twenty-five years; then a study of the area occupied by the present library, showing how valuable classroom space was being used for books-in other words, that the books could be stored in a stack more economically. There followed a comprehensive budget of what it would cost to operate a new building, as compared with the existing library, as to labor and service. There was prepared also a summary of what other colleges were doing with their library programs. Finally, there were presented photographs and statements as to the defects in the existing structure, including the possibility of loss through fire and water and the general undignified position of the most important building on the campus, namely, the library.

The report embodying all this, which must have brought blushes to the faces of some of the trustees, was very concise. It had the same effect on the trustees as a certified public accountant's financial statement would have on a bank president. It was something they could feel and understand. Furthermore, it was on a comparative basis and they could weigh it. Some of the trustees said later, "We did not know that these conditions existed." They then raised the question as to how much the proposed structure would cost to build and operate. It was not necessary to put them off until the next day or week; they were given the answer at once. Then they asked where the money was coming from and were told, in a polite way, that that was their problem-that they had been supplied with the facts to present to possible donors or to the money distributors and that that was as far as the librarian and his advisers ought to go.
If, without these facts, the trustees had been approached about a new building, their answer might well have been: "Do with what you have-it is good enough; we need money for the new chemistry building, and the library will have to wait." For the library the promise often has been "next time." All this does not mean that the librarian has to put himself where he can be misjudged. He does need to remember, however, that when he asks for something, particularly money, the questions always come back: "How do you know you need it? Why do you need it?" He must have a watertight answer.

Now for a word about the preparation of this material. It takes experience, and hard work, and there must be data, figures, and plans. The plans are the simplest part to prepare but the most important. They must not be monumental nor approached from the architect's point of view but must be functional. They must start with the concept of books waiting on shelves for readers, and the building must be designed around the circulation of books and the convenience of readers. By circulation is meant the use of the books and all the physical movements that go with it.

Where libraries have been built as purely architectural problems, they have been unsuccessful. To inject a personal note, I spent several years of my youth as a librarian in such a building. I knew the functions of a library but I was uneducated as to the planning of one, and so I could not find the reason why, for instance, the books dried out and, again, why at the end of the day we were all so tired. Later on, as I studied planning and became an architect, I found, for one thing, that we were taking many unnecessary steps and carrying loads uneconomically, because the relations among the departments had not been well conceived.

When a designer, inexperienced in library functions, proposes to place the vari- 
ous departments of a building mainly with reference to a decorative scheme, the librarian is at a disadvantage. He cannot contradict the architect on architectural points. But he should say "Away with your architectural features; let's plan a library." That is the attitude the manufacturer would take in planning a manufacturing plant.

Also, where a building is planned too small in the first place, it will prove a working failure. The effects may be that no wings can be added, the reading rooms cannot be enlarged, and the stack capacity cannot be increased. That brings up the question: what are you going to do when your completed library calls for $\$ 500,000$ and you have an allowance of only $\$ 150,000$ ?

This problem presented itself at Skidmore College. The suggestion came of building a complete structure for the allotted \$150,000. Such a building would have contained everything needed but would have been so small that no part could have been enlarged. When reading rooms and offices are in their proper places it is not possible to blow them up to double size. The solution was to make the over-all plans for a complete $\$ 500,000$ building to be erected in the future but to put up immediately only a stack and to leave out the top tier of that so that its space could be used for a reading room. When in time a reading room is provided on the first floor and new wings are added to the original building, the temporary reading room on the top floor can be converted into book space.

It has worked perfectly. True, the stack may be considered the most prosaic part of the building - the one that would have the least appeal to possible donors. There is no architectural glory about it. Necessarily, there were left out the parts which would contain the main lobby, the big reading room, and the architectural façade. These are all for future donors to think of. As has been indicated, it may soon be comparatively easy to get hearings on the needs of our libraries. Librarians may have a good chance to secure the buildings they have been thinking about for a long time. But they have a great responsibility. These buildings will be finished and crystallized without possibility of change for the next fifty years. If they are not well thought out and designed, they will be failures.

So, librarians must plan intelligently: first, the campaigns to present their problems; then, the actual buildings. They must know their needs and must set these up in such a form as to be understood quickly and clearly. They must be ready with all the answers if the most is to be made of the present opportunity.

\section{A.C.R.L. Nominating Committee, I945/46}

Benjamin E. Powell, librarian, University of Missouri, Columbia, chairman

William H. Carlson, associate librarian, University of Washington, Seattle

Mabel L. Conat, reference librarian, Public Library, Detroit

Hazel A. Johnson, librarian, Palmer Library, Connecticut College, New London John Van Male, librarian, Madison Memorial Library, Madison College, Harrisonburg, $\mathrm{Va}$. 